\title{
Hukum Adat Masyarakat Hindu Asal Bali Sebagai Pedoman dalam Menjalankan Kehidupan Bermasyarakat dan Beragama di Desa Sebamban III Kecamatan Sungai Loban Kabupaten Tanah Bumbu Provinsi Kalimantan Selatan.
}

Oleh: Budhi Widodo

Sistem hukum yang berlaku di Indonesia masih pluralistis dimana masih berlaku beberapa sistem hukum dalam masyarakat. Selain hukum positif juga diakui berlakunya hukum kebiasaan atau hukum adat di seluruh wilayah tanah air begitujuga di wilayah Kalimantan khususnya bagi masyarakat Bali yang bermukim di wilayah Desa Sebambam III Kecamatan Sungai Lobam Kabupaten Tanah Bumbu Provinsi Kalimantan Selatan. Hal ini tentunya dilatarbelakangi oleh kondisi masyarakat kita yang sangat heterogen sehingga masing-masing suku dan daerah memiliki adat istiadat serta hukum adatnya sendiri-sendiri yang diakui, dipatuhi sebagai sebuah norma yang turut mengatur kehidupan sosial masyarakat adat.Pendekatan penelitian hukum empiris (sosiologis) khususnya kepada penelitian hukum yang tidak tertulis dengan pendekatan penelitian diskriptif kualitatif. "Pendekatan atau metode kualitatif adalah metode yang mengungkap fakta-fakta secara mendalam berdasarkan karakteristik ilmiah dari individu atau kelompok untuk memahami dan mengungkap sesuatu dibalik fenomena".

Masyarakat Hindu di Desa Sebamban III Kecamatan Sungai Loban memiliki tradisi hukum adat yang sampai saat ini masih dipertahankan keberadaannya dalam lingkungan masyarakat yang berfungsi sebagai pengendali sosial masyarakat. Bentuk hukum kebiasaan adat tertuang dalam bentuk aweg-aweg atau aturan kebiasaan masyarakat Hindu asal Bali yang ada di desa Sembanbam III.Fungsi Awig-Awig bagi Masyarakat Hindu asal Provinsi Bali dalam Menjaga Ketertiban Bermasyarakat dan Beragama di Desa Sebamban III Kecamatan Sungai Loban Kabupaten Tanah Bumbu.Awig-awig tumbuh dari bawah yaitu dari ketulusan masyarakat adat untuk kepentingan ketentraman dan keharmonisan masyarakat adat itu sendiri.

Sedangkan penerapan sanksi mengacu kepada moto "Desa mawa cara, negara mawa tata" yang memiliki pengertian bahwa setiap tempat, masyarakat dan kaum memiliki caracara tersendiri dalam segala hal. Termasuk dalam waktu pelaksanaan penerapan sanksi dalam awig-awig yaitu pada saat adanya kegiatan di Pura seperti rapat, gotong royong, ngayah maupun kegiatan-kegiatan lainnya yang dilakukan oleh Kelihan Desa bersama 
seluruh anggota masyarakat yang beragama Hindu bahkan sanksi terberat sampai pemberian denda berupa harta.

\section{Kata Kunci: Hukum Adat, Hindu Bali, Pedoman Bermasyarakat dan Beragama}

\section{Pendahuluan}

Sistem hukum yang berlaku di Indonesia masih pluralistis dimana masih berlaku beberapa sistem hukum dalam masyarakat kita. Selain hukum positif juga diakui berlakunya hukum kebiasaan atau hukum adat di seluruh wilayah tanah air begitujuga di wilayah Kalimantan khususnya bagi masyarakat Bali yang bermukim di wilayah Desa Sebambam III Kecamatan Sungai Lobam Kabupaten Tanah Bumbu Provinsi Kalimantan Selatan.Kenyataan ini tentunya dilatarbelakangi oleh kondisi masyarakat kita yang sangat heterogen sehingga masing-masing suku dan daerah memiliki adat istiadat serta hukum adatnya sendiri-sendiri yang diakui, dipatuhi sebagai sebuah norma yang turut mengatur kehidupan sosial masyarakat adat.

Dalam konstitusi dasar negara kita yaitu pasal 18 B ayat (2) Undang-Undang Dasar Tahun 1945 dimana ditegaskan bahwa;

Negara mengakui dan menghormati kesatuan-kesatuan masyarakat hukum adat beserta hak-hak tradisionalnya sepanjang masih hidup dan sesuai dengan perkembangan masyarakat dan prinsip Negara Kesatuan Republik Indonesia, yang diatur dalam undang-undang.

Karena sifat dari hukum adat yang sangat dinamis, dimana dapat mengikuti perkembangan dari masyarakat adat itu sendiri sehingga seperti kita ketahui di berbagai wilayah hukum adat dan masyarakat adat tertentu implementasi dan eksistensi bentuk dan sanksi hukum adat masih berlangsung hingga saat ini tanpa terkecuali:Hukum Adat Masyarakat Hindu Asal Bali Sebagai Pedoman dalam Menjalankan Kehidupan Bermasyarakat dan Beragama di Desa Sebamban III Kecamatan Sungai Loban Kabupaten Tanah Bumbu Provinsi Kalimantan Selatan.

Atas dasar itulah penulis tertarik untuk menggali dan meneliti tentang; Hukum Adat Masyarakat Hindu Asal Bali Sebagai Pedoman dalam Menjalankan Kehidupan Bermasyarakat dan Beragama di Desa Sebamban III Kecamatan Sungai LobanKabupaten Tanah Bumbu Provinsi Kalimantan Selatan.Dari uraian latarbelakang di atas 
penulismerumuskan beberapa permasalahan yang akan dikaji diantaranya: 1) Bagaimana Bentuk-bentuk Hukum Adat Masyarakat Hindu Asal Bali di Desa Sebamban III Kecamatan Sungai Loban Kabupaten Tanah Bumbu Provinsi Kalimantan Selatan. 2) Apa saja JenisjenisSanksi Hukum Adat yang masih berlaku dalam hukum adat Masyarakat Hindu Asal Bali di Desa Sebamban III Kecamatan Sungai Loban Kabupaten Tanah Bumbu Provinsi Kalimantan Selatan.

\subsection{Pengertian Hukum Adat}

Prof. Hilman Hadikusuma dalam bukunya Pengantar Ilmu Hukum Adat Indonesia menyatakan bahwa hukum adat adalah aturan kebiasaan manusia dalam hidup bermasyarakat, dimana sejak manusia diturunkan Tuhan kemuka bumi, maka ia memulai hidupnya berkeluarga selanjutnya menjalani hidup bermasyarakat dan kemudian bernegara.Sejak manusia berkeluarga mereka telah mengatur dirinya dan anggota keluarganya menurut kebiasaan mereka, dimana perilaku kebiasaan tersebut berlangsung secara terus menerus menimbulkan kebiasaan pribadi dan jika kebiasaan tersebut dilakukan secara bersama- sama dalam suatu keluarga maupun dalam suatu masyarakat maka lambat laun kebiasaan tersebut akan menjadi 'adat' dari masyarakat yang bersangkutan (2003: 1).

Jadi adat adalah kebiasaan-kebiasaan dari suatu kelompok masyarakat tertentu, dan dalam perkembanganya kelompok masyarakat yang bersangkutan menjadikan kebiasaan adat tersebut sebagai suatu kebiasaan yang harus dilakukan atau dilaksanakan bagi anggota kelompoknya bahkan disertai dengan ancaman sanksi kepada anggota masyarakat yang melanggar kebiasaan tersebut sehingga lambat-laun dalam perkembangannya kebiasaan tersebut menjadi 'hukum adat' yang berlaku bagi anggota masyarakat yang bersangkutan. Sementara itu Peter Mahmud Marzuki mengemukakan, seringkali dalam masyarakat yang primitif kebiasaan diidentikan dengan hukum. (2008: 52), sebagai suatu norma sosial hukum merupakan suatu produk budaya, hukum lahir dalam masyarakat dengan bentuk budaya apapun sehingga dalam masyarakat yang dianggap primitipun hukum sudah dapat dijumpai.

Prof. R. Supomo seperti dikutif I Wayan Surpha (2006: 12) menjelaskan pengertian hukum adat adalah hukum yang hidup sebagai peraturan kebiasaan yang dipertahankan di dalam pergaulan hidup, baik di kota-kota maupun di desa-desa (Customary Law). Sementara Imam Sudiyat menjelaskan, dalam arti sempit sehari-hari yang dinamakan hukum adat adalah hukum asli yang tidak tertulis yang memberi pedoman kepada sebagian besar orang 
Indonesia dalam kehidupan sehari-hari, dalam hubungan antara satu dengan yang lainnya baik di desa maupun di kota.Sementara Prof. Sukanto menjelaskan hukum adat adalah kompleks adat yang kebanyakan tidak dibutuhkan,tidak dikodifikasikan dan bersifat paksaan (dwang) dan mempunyai akibat hukum (rechtsgevolg). Jadi menurutnya hukum adat itu keseluruhan adat yang tidak tertulis dan hidup dalam masyarakat berupa kesusilaan, kebiasaan dan kelaziman yang memiliki akibat hukum.

Prof. Bussar Muhammad, dalam bukunya Asas-asas Hukum Adat, (2002: 6) mengakui betapa sukarnya untuk memberikan definisi, dengan hanya mengemukakan dengan beberapa kata, keseluruhan pengertian, sifat dan hakekat hal yang dimaksud, karena itu suatu definisi hanya dapat dipakai sebagai suatu pegangan sementara saja.

Menurut Ter Haar seperti dikutif Bussar Muhammad, dalam ajaran "Beslissingenleer" menurut ajaran ini maka hukum adat itu dengan mengabaikan ajaran-ajaran yang tertulis yang terdiri dari peraturan-peraturan desa, surat-surat perintah raja adalah keseluruhan peraturan-peraturan yang menjelma dalam keputusan-keputusan para fungsionaris hukum (dalam arti yang luas) yang memiliki wibawa (macht) serta pengaruh (invloed) dan yang dalam pelaksanaannya berlaku secara serta merta (spontan) namun dipatuhi dengan sepenuh hati.

Dengan demikian menurut Bussar Muhammad hukum adat yang berlaku itu hanya dapat diketahui dan dilihat dalam bentuk-bentuk keputusan-keputusan para fungsionaris hukum itu, bukan saja hakim tapi juga kepala adat, rapat desa, wali tanah, petugas-petugas di lapangan agama, petugas-petugas desa lainnya (2002: 9). Namun keputusan itu bukan saja meliputi keputusan mengenai suatu sengketa yang resmi, tetapi juga keputusan diluar itu, berdasarkan nilai-nilai yang hidup sesuai dengan alam rohani dan hidup kemasyarakatan anggota masyarakat adat tersebut.

\subsection{Teori Resepsi/Penerimaan}

Seperti kita ketahui bahwa pelaksanaan adat disebagian besar wilayah di negara kita tentunya tidak terlepas dari dasar agama atau kepercayaan yang dianut oleh sebagian besar masyarakat adat dimana adat itu berlaku dan berkembang sehingga secara terus-menerus 
tetap diikuti dan dilestarikan.Dalam teori Receptio in Compleksu atau teori penerimaan yang dikemukakan Van Den Berk dijelaskan bahwa: "adat istiadat dan hukum adat suatu golongan masyarakat adalah resepsi seluruhnya dari agama yang dianut oleh golongan masyarakat itu". Hal ini berarti bahwa hukum adat suatu golongan masyarakat adalah hasil penerimaan secara penuh dari ajaran agama golongan masyarakat dimaksud.

Teori ini tentunya menimbulkan dan munculnya beragam tanggapan baik yang pro dan kontra, bahkan ada yang berpendapat jika tidak seluruhnya resepsi itu terjadi, namun hanya beberapa bagian saja dari hukum adat atau adat yang berlaku dalam masyarakat kita adalah sebagian resivir atau resepsi dari yang awalnya adalah hukum agama yang selanjutnya diserap kedalam hukum adat.Cristian Snouck Hurgronje (dalam Tolib Setiady, 2009: 30) menyatakan bahwa:

"Tidak semua bagian dari hukum agama diterima, diresepsi dalam hukum adat. Hanyalah beberapa bagian tertentu dari hukum adat yang dipengaruhi hukum agama yaitu terutama bagian-bagian hidup manusia yang berhubungan erat dengan kepercayaan dan hidup batin, bagian tersebut adalah hukum keluarga, hukum perkawinan dan hukum waris".

Meskipun demikian penulis berkeyakinan bahwa dalam kenyataan yang sebenarnya dalam masyarakat Hindu yang berasal dari Bali dalam kenyataannya masih memegang teguh kepercayaan yang dianut oleh leluhurnya dan meneruskannya hingga saat ini dan tetap memberikan nuansa tersendiri dalam kebiasaan yang berlaku dalam hukum adat bagi masyarakat adat yang bersangkutan.

\subsection{Teori Pluralisme Hukum}

Kita menyadari bahwa Negara Kesatuan Republik Indonesia (NKRI) memang berdiri dan dibangun di atas keragaman etnis, suku dan agama serta kepercayaan yang berbedabeda, karena itu kita menyadari pula berlakunya berbagai budaya dan adat istiadat yang berbeda-beda yang terdapat dalam masyarakat di seluruh wilayah Indonesia. Menyadari akan kebhinekaan dan multikulturnya budaya dan adat istiadat yang berbeda-beda tersebut maka atas dasar itulah tidak mungkin dalam bidang hukum tertentu diadakannya sebuah unifikasi hukum (baca: penyeragaman aturan hukum).

Maka dari itu hukum adat yang berlaku di berbagai wilayah masyarakat adat di seluruh wilayah Indonesia tetap tumbuh subur. Atas dasar itu juga pemerintah sampai saat ini juga masih memberikan ruang bagi berlakunya pluralisme hukum khususnya dalam hal ini 
berlakunyka hukum adat di berbagai wilayah masyarakat adat tidak terkecuali dalam wilayah hukum adat bagi masyarakat Hindu Asal Bali di Desa Sebamban III Kecamatan Sungai Loban Kabupaten Tanah Bumbu Provinsi Kalimantan Selatan.

Menurut guru besar Universitas Brawijaya Malang Prof. I Nyoman Nurjaya pluralisme hukum secara umum dimaknai sebagai suatu situasi dimana dua atau lebih sistem hukum bekerja secara berdampingan dalam suatu bidang kehidupan sosial yang sama, atau untuk menjelaskan keberadaan dua atau lebih sistem pengendalian sosial dalam suatu bidang kehidupan sosial.

Atas dasar itulah, sampai saat sekarang dan dimasa yang akan datang norma-norma hukum yang bersumber dari hukum adat atau kebiasaan masih akan dilaksanakan dan diikuti, ditaati oleh masyarakat adat yang bersangkutan, sepanjang tidak bertentangan dengan nilai-nilai, kaidah yang berlaku dalam masyarakat kita.Teori pluralisme hukum juga mengacu kepada adanya keanekaragaman sistem hukum khususnya sistem hukum adat yang masih dianut dan dilaksanakan oleh sebagian besar masyarakat adat di berbagai wilayah tanah air termasuk juga masyarakat Hindu Asal Bali di Desa Sebamban III Kecamatan Sungai Loban Kabupaten Tanah Bumbu Provinsi Kalimantan Selatan.

\section{Pembahasan}

\subsection{Sejarah Singkat Desa SebambanIII}

Desa Sebamban III merupakan bagian dari Kecamatan Sungai Loban Kabaputen Tanah Bumbu Provinsi Kalimantan Selatan. Sejak adanya pemekaran wilayah Kabupaten Tanah Bumbu, Desa Sebamban III menjadi desa bagian dari Kabupaten Tanah Bumbu. Desa Sebamban III merupakan tempat bermukim penduduk asal transmigran dari Provinsi Bali dan Provinsi Sulawesi dan masyarakat lokal desa tersebut yang mayoritas penduduknya adalah warga dari Provinsi khususnya Bali, Desa Sebamban III juga merupakan tempat bermukim penduduk pendatang atau penduduk transmigrasi dari Pulau Jawa dan Bali. Sampai saat ini, setelah pemekaran wilayah Kabupaten Tanah Bumbu.

Letak posisi Desa Sebamban III yang cukup strategis di Provinsi Kalimantan Selatan. Jarak desa Sebamban III dengan kota Palangka Raya sekitar 500 kilometer dari kota Palangka Raya dan kurang lebih 300 kilometer dari kota Banjarmasin ibukota Provinsi Kalimantan Selatan. 
Jarak tempuh Desa Sebamban III dari ibukota Kecamatan sejauh $12 \mathrm{~km}$, jarak tempuh dari ibukota kabupaten sejauh $43 \mathrm{~km}$, dan jarah tempuh dari ibukota provinsi sejauh kurang lebih $246 \mathrm{~km}$.

\subsection{Kondisi Penduduk Desa Sebamban III}

Berdasarkan data penduduk yang diberikan oleh Kepala Desa Sebamban III, Desa desa Sebamban III terdiri dari 10 RT dan 2 RW. Jumlah penduduk di desa Sebamban III Kecamatan Sungai Loban Kabupaten Tanah Bumbu terdiri dari 405 KK, keseluruhan penduduk adalah 1.438 jiwa dengan jumlah laki-laki 742 jiwa dan perempuan 696 jiwa. Data jumlah penduduk di desa Sebamban III Kecamatan Sungai Loban Kabupaten Tanah Bumbu Provinsi Kalimantan Selatan berdasarkan jenis kelamin dapat dilihat dalam tabel di bawah ini:Berdasarkan tabel diatas dapat kita ketahui bahwa jumlah antara penduduk yang berjenis kelamin laki-laki dan perempuan memiliki selisih yang tidak begitu banyak yakni 46 jiwa.

Penduduk yang berada di wilayah Desa Sebamban III terdiri dari penduduk asli Dayak dan penduduk pendatang khususnya pendatang dari pulau Jawa dan pulau Bali (melalui program transmigrasi) dan suku Banjar. Serta penduduk dari pulau Sulawesi dari suku Bugis. Sementara Komoditi unggulan di Desa Sebamban III Kecamatan Sungai Loban yaitu sektor perkebunan dan sektor pertanian. Sektor Perkebunan komoditi unggulannya adalah karet dan kelapa sawit. Sub sektor pertanian juga merupakan komoditi yang diunggulkan. Secara umum masyarakat Desa Sebamban III Kecamatan Sungai Loban Kabupaten Tanah Bumbu masyarakat yang cukup maju. Hal ini terlihat dari segi pendidikan masyarakat. Sekarang ini, sudah jarang penduduk yang benar-benar buta huruf, dan itupun terdapat dikalangan orang-orang tua di wilayah yang jauh dari pusat Kecamatan. Selebihnya, paling tidak penduduk di desa ini pernah mengenyam pendidikan, walaupun hanya sebatas SD (Sekolah Dasar), dan tidak sampai tamat. Namun untuk generasi sekarang ini rata-rata pendidikan mereka adalah SMP (Sekolah Menengah Pertama) atau SMA (Sekolah Menengah Atas), dan melanjutkan ke PT (Perguruan Tinggi) yang ada kota Banjarmasin Kalimantan Selatan maupun di Kota Palangka Raya Provinsi Kalimantan Tengah.

Sedangkan berdasarkan klasifikasi agama penduduk di wilayah Desa Sebamban III Kecamatan Sungai Loban KabupatenTanah Bumbu, masing-masing penduduk yang 
beragama Islam sebanyak 1.171 jiwa, Kristen sebanyak 3 jiwa dan Hindu sebanyak 264 jiwa. Lebih jelasnya dapat dilihat pada tabel berikut ini:Dengan kondisi yang heterogen ini tidak berarti bahwa tidak adanya kerukunan antar umat beragama, justru sebaliknya wujud toleransi di Desa Sebamban III Kecamatan Sungai Loban Kabupaten Tanah Bumbu ini tampak sekali dengan adanya sarana tempat ibadah seperti Masjid, Gereja dan Pura. Khusus untuk umat Hindu tersedia 1 (Satu) Pura Agung, 1 (Satu) Pura Dalem, dan 2 (Dua) Merajan. Masyarakat Hindu di Desa Sebamban III Kecamatan Sungai Loban Kabupaten Tanah Bumbu merupakan bagian intergal dari bangsa Indonesia yang perlu diakui eksistensinya. Bagaimana juga keberadaan masyarakat Hindu perlu mendapatkan perhatian dan dukungan agar mampu menggali potensi yang ada dalam diri, dan dapat mensejajarkan dirinya dengan umat beragama lainnya.

Selama ini terdapat pandangan dalam masyarakat, terutama yang non Hindu, bahwa agama Hindu identik dengan penyembahan berhala, klenik, penyembahan setan, dan predikat-predikat lain yang berhubungan dengan hal-hal yang sifatnya primitif. Umat Hindu yang tidak paham terhadap agamanya akan cenderung diam, berikutnya yang terjadi adalah merasa tidak percaya diri sebagai penganut Hindu. Umat Hindu seperti inilah yang rentan terhadap konversi agama. Umat Hindu yang sudah mendapatkan pembinaan dan pendidikan agama, apalagi terdapat usaha untuk memahaminya dengan baik justru akan meluruskan hal-hal yang dipandang keliru oleh penganut agama lain tentang agama Hindu.Khususnya untuk menciptakan kerukunan antar sesama (pawongan) konsep gotongroyong masih melandasi sikap kehidupan bermasyarakat mereka. Hal ini dengan masih adanya tradisi membantu yaitu membantu secara bersama-sama jika ada salah anggota masyarakat yang memiliki upacara/hajatan. Semangat saling asah, asih dan asuh mewarnai kebersamaannya.

\subsection{Sejarah singkat masuknya penduduk Bali ke Desa Sebamban}

Awal mula masyarakat Hindu melakukan transmigrasi yaitu dimana setelah peristiwa Gunung Agung meletus pada tahun 1963. Akibat bencana Gunung meletus tersebut, kehidupan ekonomi sosial masyarakat di daerah Bali terutama di Kabupaten Karang Asem dan Klungkung dan sekitarnya semakin susah. Kemudian pada tahun 1971 
Pemerintah Pusat dan Pemerintah Daerah mengadakan program transmigrasi bagi masyarakat Hindu yang ada di Bali. Program transmigrasi tersebut tidak hanya ke pulau Kalimantan tetapi juga ke pulau lain yang ada di Indonesia, seperti:Pulau Sulawesi dan Pulau Sumatera.

Menurut Kelian adat Wayan Mertayasa,(wawancara tanggal 12 Oktober2016), tujuan program transmigrasi bagi masyarakat Hindu adalah untuk mengurangi angka kemiskinan dan kepadatan penduduk yang ada di wilayah Bali, meningkatkan taraf ekonomi kehidupan masyarakat dengan memberikan kesempatan merubah nasib serta untuk meratakan persebaran penduduk di seluruh wilayah nusantara. Masuknya masyarakat Hindu ke pulau Kalimantan khususnya ke desa Sebamban III yaitu tahun 1980an, dimana awalnya desa Sebamban III merupakan bagian dari Kabupaten Kotabaru. Masyarakat Hindu yang melakukan transmigrasi ke desa Sebamban III awalnya hanya beberapa KK dan tidak sedikit yang meninggalkan tempat yang baru karena perekonomian yang sudah dan perjuangan pembukaan lahan yang penuh perjuangan.

Sementara menurut Ketut Suka (wawancara, tanggal 13/2016) menyatakan bahwa saat ini jumlah penduduk transmigrasi asal Bali yang beragama Hindu di desa Sebamban IIIberjumlah264 Jiwa. Jumlah penduduk yang saat ini lebih sedikit dibandingkan pada saat awal transmigrasi dikarenakan masyarakat Hindu banyak yang pindah ke berbagai daerah seperti ke Kota Palangka Raya, Tangkiling, Pundu, Sampit, Basarang bahkan ada yang pindah ke Plaihari. Masyarakat Hindu yang masih menetap di desa Sebamban III kebanyakan berprofesi sebagai pekebun (kebun sawit dan karet) pedagang, petani dan buruh.

\subsection{Deskripsi Analisis Data dan Hasil Penelitian}

\subsubsection{Bentuk Hukum Adat Masyarakat Hindu Asal Bali di Desa Sebamban.}

Berdasarkan hasil pengambilan data yang telah dilakukan oleh peneliti tentang Hukum Adat Masyarakat Hindu Asal Bali di Desa Sebamban III Kecamatan Sungai Loban Kabupaten Tanah Bumbu Provinsi Kalimantan Selatan.Masyarakat Hindu di wilayah Desa Sebamban III Kecamatan Sungai Loban memiliki tradisi hukum adat atau hukum kebiasaan yang sampai saat ini masih dipertahanakan keberadaannnya dalam lingkungan masyarakat yang berfungsi sebagai pengendali sosial masyarakat. Bentuk hukum kebiasaan 
adat masyarakat Desa Sebamban III tertuang dalam bentuk aweg-aweg atau aturan kebiasaan masyarakat Hindu asal Bali yang ada di desa Sembanbam III.

Fungsi Awig-Awig bagi Masyarakat Hindu asal Prov. Bali dalam Menjaga Ketertiban Bermasyarakat dan Beragama di Desa Sebamban III Kecamatan Sungai Loban Kabupaten Tanah Bumbu dari hasil wawancara yang didukung dengan observasi secara langsung sebagai berikut:Peraturan atau hukum kebiasaan masyarakatat bali atau biasa disebut awig-awig itu tumbuh dari bawah yaitu dari ketulusan masyarakat adat untuk kepentingan ketentraman dan keharmonisan masyarakat adat itu sendiri. Sementara, saat ini peraturan yang diberlakukkan bagi warga masyarakat untuk mengatur kehidupan dalam rangka menjalankan kehidupan bernegara, selalu berdasarkan kepada landasan dasar berlakunya aturan tersebut.

Awig-awig yang tumbuh dan mengikuti perkembangan masyarakat mempunyai kekuatan berlaku karena ia lekat dan diperlakukan karena dirasa mutlak untuk menjamin situasi yang tentram dan damai dalam kehidupan masyarakat. Sedangkan dari sudut kekuatan berlakunya yang justru sering diberikan oleh penguasa sebagai landasan hukum yang tegas dapat disebutkan sejumlah pasal-pasal perundang-undangan yang saling berkaitan. Berdasarkan teori Efektivitas Hukum, adapun yang menjadi landasan daripada hukum adat atau kebiasaan adat termasuk di dalamnya aweg-aweg ini sendiri adalah melalui Pasal 18B ayat (2) UUD 1945 yang menyatakan sebagai berikut:

"Negara mengakui dan menghormati kesatuan-kesatuan masyarakat hukum adat beserta hak-hak tradisionalnya sepanjang masih hidup dan sesuai dengan perkembangan masyarakat dan prinsip Negara Kesatuan Republik Indonesia, yang diatur dalam undangundang”.

Sebagai masyarakat hukum adat, maka berdasarkan Pasal 18B ayat (2) UUD 1945 keberadaan desa adat beserta hak-hak tradisionalnya diakui dan dihormati oleh Negara. Salah satu hak tradisional desa adat adalah membuat awig-awig, disamping menyelenggarakan pemerintahan sendiri, serta menyelesaikan persoalan-persoalan hukum yang terjadi diwilayahnya, baik yang berupa sengketa ataupun pelanggaran adat. Semua itu merupakan bagian dari pelaksanaan otonomi desa adat. Dengan demikian, landasan konstitusional kewenangan desa adat untuk membuat awig-awig dalam konstitusi terletak pada Pasal 18 B ayat (2) UUD 1945. 
Menurut I Ketut Aman, SH menjelaskan, (wawancara tanggal 13 Oktober 2016), diterapkannya peraturan di desa Sebamban III ialah sejak umat beragama Hindu yang berasal dari transmigrasi asal Bali pada tahun 1980an dan diperkirakan pada tahun 1980 masyarakat setempat mulai mengadakan musyawarah untuk membuat suatu aturan di desa tersebut. Aturan itu hanya berlaku bagi masyarakat Hindu yang ada di Desa Sebamban III dan belum memiliki dasar hukum yang kuat, sehingga aturan itu hanya bersifat biasa tanpa adanya suatu sanksi atau hukuman bagi yang melanggar.

Menurut Mangku I Ketut Suarna, (wawancara tanggal 12 Oktober 2016) berdasarkan UUD 1945 Pasal 18B ayat 2, masyarakat desa Sebamban III kemudian melakukan musyawarah yang dipimpin oleh Kelihan Desa pertama desa Sebamban III yaitu. Dari hasil musyawarah tersebut, menghasilkan beberapa pokok aturan-aturan yang diberlakukan di desa tersebut. Aturan itu berupa awig-awig yang tidak tertulis (tidak dibuat dalam pembukuan) yang telah disepakati bersama oleh semua masyarakat Hindu yang ada di desa Sebamban III Kecamatan Sungai Loban Kabupaten Tanah Bumbu Provinsi Kalimantan Selatan. Jadi, acuan atau dasar hukum masyarakat Hindu di desa Sebanban III membuat awig-awig adalah berdasarkan UUD 1945 Republik Indonesia Pasal 18B Ayat 2 dan juga kesepakatan seluruh warga masyarakat Hindu yang ada di desa tersebut.

\subsubsection{Jenis Sanksi dan Fungsi Awig-Awig Bagi Masyarakat Hindu Asal Provinsi Bali di Desa Sebamban III Kecamatan Sungai Loban Kabupaten Tanah Bumbu Provinsi Kalimantan Selatan.}

Kata fungsi merupakan kegunaan, pekerjaan atau jabatan, tindakan atau kegiatan perilaku dan kategori bagi aktivitas-aktivitas. (Komaruddin, 1994:168). Dalam Kamus Besar Bahasa Indonesia (Tim Penyusun, 2001:322) mendefinisikan bahwa fungsi adalah jabatan (pekerjaan) yang dilakukan dan kegunaan suatu hal.Dari definisi diatas bisa disimpulkan bahwa fungsi memiliki arti pekerjaan dan pola perilaku yang diharapkan dari seseorang dalam manajemen dan ditentukan berdasarkan status yang ada padanya.

Berdasarkan teori fungsional struktural pelaksanaan dari penerapan sanksi dalam awig-awig dapat dipandang sebagai organisme yang memiliki struktur dan fungsi masingmasing pada penerapan sanksi dalam awig-awig tersebut. Awig-awig adalah peraturanperaturan hidup bersama bagi masyarakat desa di desa adatnya, untuk mewujudkan 
kehidupan yang aman, tentram, tertib, dan sejahtera di desa adat. Awig-awig itu memuat aturan-aturan dasar yang menyangkut wilayah adat, krama desa adat, keagamaan serta sanksi. Awig-awig merupakan hukum adat yang mempunyai fungsi untuk menjaga kebersamaan, kedisiplinan, kekompakkan dari semua masyarakat desa sehingga kegiatan sekecil apapun dilakukan secara bersama-sama.

Menurut I Wayan Mertayasa, fungsi dari diterapkannya sanksi dalam awig-awig di desa Sebamban III adalah untuk mengatur dan mengendalikan prilaku warga masyarakat dalam pergaulan hidupnya guna mencapai ketertiban dan ketentraman masyarakat, untuk mengintegrasikan warga masyarakat dalam suatu persatuan dan kesatuan yang hidup bersama sepenanggungan dan seperjuangan sedangkan arti penting awig-awig adalah merupakan pengikat persatuan dan kesatuan masyarakat desa guna menjamin kekompakan dan keutuhan dalam manyatukan tujuan bersama mewujudkan kehidupan yang aman, tertib, dan sejahtera di wilayah desa tersebut.

Mangku I Ketut Suarnamenjelaskan bahwa fungsi awig-awig didalam kehidupan masyarakat mempunyai nilai yang sangat menentukan didalam menata kehidupan masyarakat, oleh karena itu adat istiadat bersifat dinamis disamping merupakan pengikat yang seolah-olah memaksa para masyarakat desa untuk bertindak sesuatu demi kehidupan kolektifnya dapat terus berlangsung. Dalam penerapannya awig-awig merupakan aturanaturan yang dibuat oleh masyarakat yang diikuti dengan adanya sanksi-sanski hukum yang dapat menjamin kewibawaan demi tegaknya nilai-nilai dari peraturan-peraturan yang berlaku, untuk menuntun suatu hubungan yang harmonis dalam kehidupan di masyarakat. Sesuai dengan hasil pengamatan yang dilakukan tempat pelaksanaan penerapan sanksi dalam awig-awig dilaksankan di Pura.

Menurutnya tempat pelaksanaan penerapan sanksi dalam awig-awig itu menyesuaikan dengan konsep yang dimiliki oleh agama Hindu yaitu konsep desa, kala dan patra, artinya menyesuaikan dengan keadaan tempat waktu, situasi dan kondisi. Sedangkan waktu pelaksanaan Penerapan sanksi dalam awig-awig, Mangku mengatakan "Desa mawa cara, Negara mawa tata". Artinya setiap tempat, masyarakat dan kaum memiliki cara-cara tersendiri dalam segala hal. Termasuk dalam waktu pelaksanaan penerapan sanksi dalam awig-awig yaitu pada saat adanya kegiatan di Pura seperti rapat, gotong Royong, Ngayah 
maupun kegiatan-kegiatan lainnya yang dilakukan oleh Kelihan Desa bersama seluruh anggota masyarakat yang beragama Hindu.

Sementara I Ketut Wirta (wawancara, 13/10/2016) menjelaskan, yang menjadi pemimpin pelaksanaan penerapan sanksi dalam awig-awig bagi umat Hindu di desa Sebamban III Kecamatan Sungai Loban Kabupaten Tanah Bumbu adalah seorang Kelihan Desa. Dimana kelihan Desa yang bertugas mengatur tentang jalannya dari awig-awig yang ada dan Kelihan Desa merupakan pedoman yang sangat dominan di dalam menjalankan pemerintahan di desa tersebut. Selain memiliki tugas mengatur tentang awig-awig dan pedoman dalam menjalankan pemerintahan desa, kelihan desa juga memiliki beberapa tugas penting lainnya, antara lain:1) Memimpin rapat desa di Pura.2) Mengawasi pelaksanaan awig-awig yang ada di desa. 3) Bertanggungjawab terhadap properti atau sarana dan prasarana yang ada di desa dan menentukan tata cara pengunaan peralatan tersebut apabila diperlukan oleh masyarakat desa. 4) Membimbing masyarakat Hindu apabila diperlukan, menyaksikan dan mengesahkan setiap upacara yang dilakukan oleh warga desa terutama dalam hal pernikahan.5) Menjadi juru bicara apabila ada pertemuan di tingkat yang lebih tinggi, semisal pertemuan di tingkat kabupaten. 6) Membacakan dan mengumumkan segala keputusan yang diputuskan melalui rapat.Jika kelihan desa berhalangan hadir maka yang menjadi pemimpin dalam suatu kegiatan yang dilakukan adalah Sekretaris Kelihan Desa atau yang dipercayai.

\subsubsection{Beberapa Jenis Sanksi Dalam Awig-Awig Bagi Masyarakat Hindu Asal Bali di Desa Sebamban III Kecamatan Sungai Loban.}

Dalam aweg-aweg yang ditetapkan oleh seluruh masyarakat di desa Sebamban III kecamatan Sungai Loban kabupaten Tanah Bumbu terdapat berbagai jenis sanksi yang diberlakukan kepada masyarakat yang dianggap mengabaikan aturan yang telah ditetapkan dalam aweg aweg tersebut diantarannya sebagai berikut: 1) Denda dengan tenaga, denda/sanksi yang dimaksud yaitu; melakukan kegiatan gotong royong.2) Denda artha, denda /sanksi yang dimaksud yaitu : berupa pembayaran sejumlah uang atau harta benda. 3) Denda penghasilan, denda / sanksi yang dimaksud yaitu berupa pembayaran sejumlah barang dan uang. 4) Denda kesepekang (dikucilkan), denda / sanksi yang dimaksud yaitu: tidak diajak ngomong / mekrama desa bagi krama yang melanggar ketentuan awig-awig. 
5)Hukuman dalam bentuk upacara agama seperti, melakukan upakara pakeling di Pura Kahyangan Tiga untuk menyucikan dan menyeimbangkan unsur skala dan niskala (dunia akhirat).

Berdasarkan hasil wawancara, menurut Wayan Mertayasa(wawancara, 13/10/2016) mengatakan bahwa jenis sanksi yang terdapat dalam awig-awig di desa Sebamban III adalah sebagai tersebut diatas. Tetapi, sanksi yang sering diberlakukan kepada masyarakat di desa Sebamban III yang melanggar berupa sanksi ringan yaitu Denda Artha dan Denda Penghasilan. Dimana, masyarakat di desa Sebamban III hanya melakukan pelanggaran awig-awig yang sifatnya ringan, seperti tidak mengikuti kegiatan gotong royong dalam pemeliharaan lingkungan Pura yang dilaksanakan 1 (satu) bulan sekali seperti kegiatan gotong royong sehari sebelum pelaksanaan persembahyangan Purnama atau Tilem. Bagi masyarakat yang tidak mengikutinya, maka akan dikanakan denda.

Jika ada kegiatan gotong royong yang bersifat membangun atau membuat prasarana di dalam lingkungan Pura seperti, membangun prasarana Pura, membangun tempat persembahyangan, memperbaiki bangunan Pura yang rusak, membuat Balai Piasan atau kegiatan-kegiatan lainnnya yang tidak hanya rutin dilakukan dalam waktu 1 (satu) bulan, maka bagi masyarakat Hindu yang tidak mengikuti pelaksanaan gotong royong tersebut dikenakan sanksi yang lebih besar yaitu membayar uang besarnya sukarela per hari. Hasil pembayaran uang denda tersebut menjadi pemasukan uang kas Pura.

Wayan menambahkan (wawancara, 13/10/2016), selain kegiatan gotong royong rutin yang diadakan setiap 1 (satu) bulan 1 (satu) kali, ada juga kegiatan ngayah yang dilaksanakan pada saat piodalan atau hari raya keagamaan yang kegiatannya dilaksanakan beberapa kali dalam 1 (satu) tahun. Dimana pelaksanaan upakara tersebut bersifat upakara kecil dan upakara besar. Dalam pelaksanaan upakara kecil biasanya banten dibuat secara bergiliran oleh warga masyarakat di desa tersebut dan apabila ada warga yang mendapat giliran tetapi tidak membuat banten yang telah ditentukan, maka warga tersebut dikenakan sanksi.

Sedangkan dalam pelaksanaan upakara besar, biasanya banten dibuat oleh warga desa di Pura secara bersama-sama. Setiap kepala keluarga wajib menyerahkan atau melakukan urunan berupa beras, ketan, kelapa, ayam, telor itik, minyak goreng, janur, dan 
kayu bakar untuk meringankan pengeluaran dari uang kas Pura. Jika ada warga yang tidak mampu urunan berupa sarana upakara, maka dapat membayar berupa uang sesuai dengan nilai bahan yang telah diwajibkan. Serta jika dalam Ngayah Piodalan Besar 1 (satu) hari tidak dapat mengikuti Ngayah maka dikenakan sanksi berupa membayar uang per hari. Berdasarkan uraian diatas, bentuk dari pelanggaran awig-awig yang dilakukan oleh masyarakat serta jenis sanksi yang diberikan bagi masyarakat yang melanggar. Lebih jelasnya dapat dilihat dalam tabel berikut ini:

Bentuk Pelanggaran Awig-Awig dan Jenis Sanksi

\begin{tabular}{|c|c|c|}
\hline No & Bentuk Pelanggaran Awig-Awig & Jenis Sanksi \\
\hline 1. & $\begin{array}{l}\text { Warga masyarakat/umat Hindu yang tidak } \\
\text { mengikuti kegiatan gotong royong yang } \\
\text { dilaksanakan satu bulan sekali (gotong } \\
\text { royong rutin sehari sebelum kegiatan } \\
\text { persembahyangan di Pura). }\end{array}$ & $\begin{array}{l}\text { Membayar denda } \\
\text { berupa uang }\end{array}$ \\
\hline 2. & $\begin{array}{l}\text { Warga masyarakat/umat Hindu yang tidak } \\
\text { mengikuti kegiatan gotong royong yang } \\
\text { dilaksanakan satu bulan sekali (yang bersifat } \\
\text { membangun prasarana Pura). }\end{array}$ & $\begin{array}{l}\text { Membayar denda } \\
\text { berupa uang } \\
\text { (Nilainnya sukarela) }\end{array}$ \\
\hline 3. & $\begin{array}{l}\text { Warga masyarakat/umat Hindu yang sudah } \\
\text { mendapat giliran membuat banten dalam } \\
\text { Upacara kecil tetapi tidak membuatnya. }\end{array}$ & $\begin{array}{l}\text { Membayar denda } \\
\text { berupa uang }\end{array}$ \\
\hline 4. & $\begin{array}{l}\text { Warga masyarakat/umat Hindu yang tidak } \\
\text { menyerahkan atau melakukan urunan yang } \\
\text { telah ditentukan pada saat Upacara besar. }\end{array}$ & $\begin{array}{l}\text { Membayar sesuai } \\
\text { dengan nilai bahan } \\
\text { yang telah diwajibkan }\end{array}$ \\
\hline 5. & $\begin{array}{l}\text { Warga masyarakat/umat Hindu yang tidak } \\
\text { mengikuti kegiatan Ngayah dalam Piodalan } \\
\text { di Pura. }\end{array}$ & $\begin{array}{l}\text { Membayar denda } \\
\text { berupa uang }\end{array}$ \\
\hline 6. & $\begin{array}{l}\text { Warga masyarakat/Umat Hindu yang } \\
\text { melakukan perbuatan yang membuat }\end{array}$ & $\begin{array}{l}\text { Diberi hukuman } \\
\text { ringan sampai berat }\end{array}$ \\
\hline
\end{tabular}




\begin{tabular}{|c|l|l|}
\hline & kotornya lingkungan desa secara niskala & (dikucilkan) \\
\hline 7. & Umat Hindu yang akan melakukan kremasi & Diwajibkan membayar \\
& $\begin{array}{l}\text { sementara dalam kesehariannya sudah tidak } \\
\text { panunjung batu sesuai }\end{array}$ \\
lagi menjadi krame desa (anggota desa) & dengan kemampuan \\
\hline
\end{tabular}

Dalam prakteknya semua hasil pembayaran sanksi atau danda tersebut dikelola oleh Kelihan Desa sebagai pemasukan uang kas Pura. Namun sampai saat ini masyarakat di desa Sebamban III tidak pernah melakukan pelanggaran awig-awig yang bersifat berat, hanya sanksi yang bersifat pembayaran uang denda saja yang sering diberlakukan sehingga sanksi dalam bentuk lainnya tidak pernah diterapkan bagi masyarakat desa yang melanggar awig-awig tersebut.Dalam hal ini masyarakat sangat memberikan toleransi kepada umat atau warga disini. Dicontohkannya kepada umat yang memang asli sini dan memeluk agama hindu namun dalam kenyataannya dia merantau ke daerah lain sehingga tidak bisa memenuhi kewajibannya, namun ketika mereka meninggal dan akan mengadakan upacara ritual kematiannya di kampungnya kembali (Sebamban III) kami akan tetap menerima dengan catatan menyelesaikan biaya yang diperlukan untuk upacara ritual tersebut.

Menurut Kelihan Desasetempat selama ini yang menjadi hambatan penerapan sanksi dalam awig-awig di desa Sebamban III yaitu belum adanya suatu pemahaman dan pengertian oleh masyarakat desa itu sendiri mengenai awig-awig yang diterapkan dalam masyarakat, karena belum adanya sosialisasi secara terus-menerus kepada masyarakat desa oleh para perangkat desa dalam hal ini dilakukan oleh Kelihan Desa (Ketua Adat) dan juga para perangkat desa lainya. Disamping itu pula seperti dijelaskan oleh Ketut(wawancara, 13/10/ 2016) mengatakan bahwa terdapat beberapa hambatan-hambatan dalam penerapan sanksi awig-awig ialah dimana Kelihan Desa umumnya tidak mengetahui bahwa dirinya mempunyai kewenangan untuk bertindak sebagai Hakim Perdamaian Desa, sehingga adanya keragu-raguan dalam penerapan sanksi atau menyelesaikan sengketa-sengketa adat terjadi di desanya, hal ini jelas sangat menghambat dan mempengaruhi dalam bertindak atau menerapkan sanksi-sanksi yang tercantum dalam awig-awig di desa Sebamban III, karena itu dia mengharapkan kesadaran dari seluruh umat yang ada di sama untuk selalu bersama-sama membangun desa dan mentaati segala aturan yang telah dibuat bersama (baca: aturan yang telah tertuang dalam aweg-aweg). 
Penerapan aweg-aweg tentunya memiliki dampak tersendiri seperti dijelaskan mangku Ketut Suarna, mengatakan dampak dari diterapkannya sanksi dalam awig-awig yaitu berupa dampak yang sangat positif. Dimana penerapan sanksi dalam awig-awig berupaya untuk: 1) Selalu mengadakan pendekatan terhadap masyarakat desa mengenai pentingnya memelihara rasa persatuan dan kesatuan ditingkat desa guna terciptanya keadaan yang aman, tentram tertib di lingkungan desa. 2) Lebih mementingkan dan meningkatkan persatuan dan kesatuan demi ajegnya desa Sebamban III khususnya dan Indonesia pada umumnya. 3) Menghilangkan kebiasaan-kebiasaan negatif yang hidup di masyarakat. 4) Desa diharapkan mampu menumbuhkan serta mengaktifkan kegiatan yang ada di lingkungan desa. 5) Lembaga Desa selalu netral dalam bidang kasta atau warna yang ada di masyarakat khususnya yang ada kaitannya dengan upacara. 6) Mengadakan suatu sistem komunikasi yang terbuka dengan seluruh masyarakat agar mampu mengikuti dan menghormati kebiasaan dan adat istiadat yang berlaku di Desa Sebamban III Kecamatan Sungai Loban. 7) Desa sebagai organisasi musyawarah untuk mufakat, selalu menyediakan diri untuk mengadakan dialog atau musyawarah dengan tokoh-tokoh masyarakat dan pemuka agama yang berada di wilayah Desa Sebamban III Kecamatan Sungai Loban untuk bersama-sama mengadakan suatu tukar pikiran. 8) Memupuk rasa kekeluargaan dan solidaritas dalam kebersamaan terhadap masyarakat desa melalui pesangkepan atau mengaktifkan sekaha teruna (organisasi kepemudaan) dengan tujuan untuk melestarikan kesenian dan kebudayaan juga bertujuan untuk membina rasa kekeluargaan dan rasa persatuan untuk menciptakan tatanan hubungan harmonis setiap masyarakat desa di dalam wilayah Desa Sebamban III.

Jika penerapan sanksi dalam awig-awig tidak diterapkan maka akan menimbulkan dampak yang sangat negatif terutama bagi masyarakat Hindu di Desa Sebamban III Kecamatan Sungai Loban KabupatenTanah Bumbu Provinsi Kalimantan Selatan, dampak tersebut antara lain akan mengakibatkan ketidakharmonisan dalam bermasyarakat dan menimbulkan perselisihan antar warga masyarakat, contohnya dalam kegiatan gotong royong, ngayah atau kegiatan yang bersifat keagamaan hanya ada beberapa warga masyarakat yang hadir meskipun kegiatan sudah diberitahukan atau diumumkan oleh kelihan desa (pengurus), sehingga kegiatan tersebut tidak berjalan dengan maksimal. Dalam hal ini kesadaran masyarakat atau umat untuk melakukan kerjasama dalam kegiatan 
ritual keagamaan masih perlu ditingkatkan lagi sehingga terjadi harmonisasi ke depan dalam setiap ritual keagamaan yang dilaksanakan oleh umat.

\section{Kesimpulan}

Masyarakat Hindu asal provinsi b ali yang berada di wilayah Desa Sebamban III Kecamatan Sungai Loban memiliki tradisi hukum adat yang sampai saat ini masih dipertahankan keberadaannya dalam lingkungan masyarakat yang berfungsi sebagai pengendali sosial masyarakat. Bentuk hukum kebiasaan adat tertuang dalam bentuk awegaweg atau aturan kebiasaan masyarakat Hindu asal Bali yang ada di desa Sembanbam III.Fungsi Awig-Awig bagi Masyarakat Hindu asal Provinsi Bali dalam Menjaga Ketertiban Bermasyarakat dan Beragama di Desa Sebamban III Kecamatan Sungai Loban Kabupaten Tanah Bumbu.Awig-awig tumbuh dari bawah yaitu dari ketulusan masyarakat adat untuk kepentingan ketentraman dan keharmonisan masyarakat adat itu sendiri.

Sedangkan penerapan sanksi mengacu kepada moto "Desa mawa cara, negara mawa tata" yang memiliki pengertian bahwa setiap tempat, masyarakat dan kaum memiliki cara-cara tersendiri dalam segala hal. Pelaksanaan penerapan sanksi dalam awigawig yaitu pada saat adanya kegiatan di Pura seperti rapat, gotong royong, ngayah maupun kegiatan-kegiatan lainnya yang dilakukan oleh Kelihan Desa bersama seluruh anggota masyarakat yang beragama Hindu bahkan sanksi terberat sampai pemberian denda berupa harta.

\section{Daftar Pustaka}

Achmad Ali. 2009. Menguak Teori Hukum (Legal Theory) dan Teori Peradilan (Judicial Prudence). Kencana Prenada Media Group. Jakarta.

Bushar Muhammad.2002. Asas-Asas Hukum Adat (Suatu Pengantar). PT. Pradnya Paramita. Jakarta.

Hilman Hadikusuma. 2003. Pengatar Ilmu Hukum Adat Indonesia.CV. Mandar Maju. Bandung.

I Nyoman Nurjaya. 2008, Pengelolaan Sumber Daya Alam dalam Perspektif Antropologi Hukum.Prestasi Pustakan Publisher. Jakarta.

I Wayan Surpha.2006. Seputar Desa Pakraman dan Adat Bali. Pustaka Bali Post. Denpasar. 
Nila Riwut. 2003, Tjilik Riwut Sanaman Mantikey, Maneser Panatau Tatu Hiang: Menyelami Kekayaan Leluhur. Pusaka Lima. Palangkaraya.

Peter Mahmud Marzuki. 2008. Pengantar Ilmu Hukum. Kencana Prenada Media Group. Jakarta.

Biro Hukum Setda Provinsi Kalimantan Tengah. 2008. Hukum Adat Dayak Blaman Kabupaten Lamandau.

Peraturan Perundang-Undangan:

Undang-Undang Dasar Tahun 1945 Amandemen, Pertama, Kedua, Ketiga dan Keempat. 